\title{
GAME ONLINE DAN PENGARUH INTERAKSI SOSIAL DI KALANGAN MAHASISWA UNIVERISTAS MUHAMMADIYAH SURAKARTA
}

\author{
Salsabilla Senja Safitri \\ Universitas Muhammadiyah Surakarta
}

salsabillasenjasafitri1512@gmail.com

\begin{tabular}{|l|l|l|}
\hline Receive: $10 / 09 / 2020$ & Accepted: $10 / 10 / 2020$ & Published: $30 / 10 / 2020$ \\
\hline
\end{tabular}

\begin{abstract}
Abstrak
Tujuan dari penelitian ini adalah memahami bagaimana interaksi sosial mahasiswa pecandu game online dengan lingkungan sosial hubungannya akan menjadi kurang baik dan komunikasi secara langsung akan terganggu dan memahami bahwa tidak selalu game online mempunyai dampak negatif karena manusia mampu menciptakan kreatifitas dari temuan-temuan baru seperti permainan online atau bisa disebut game online.

Sampel penelitian ini diambil menggunakan metode kualitatif yaitu penelitian yang mempelajari tentang fenomena yang terjadi. Penelitian ini tidak menggunakan penelitian yang baku, tujuan penelitian ini mencari dan memahami yang terdapat dalam data, mengumpulkan data dengan prinsip fenomenologis dan penelitian tersebut disebut penelitian inquiri naturalistik mendalami penelitian yang sifatnya alamiah. Total 7 informan surakarta melalui wawancara secara tidak langsung untuk mengetahui dampak game online dalam interaksi sosial baik negatif maupun positif.

Hasil analisis data dalam penelitian ini menunjukkan bahwa terdapat pengaruh negatif dan positif game online dalam interaksi sosial yang mereka lakukan. Pengaruh negatif yaitu banyak menghabiskan waktunya dalam bermain game online akan menjauhkan mereka dengan kehidupan dunianya. Sedangkan pengaruh positif yaitu mampu berinteraksi dengan cara berkomunikasi dalam game online karena adanya keterjangkauan jarak untuk bertemu. Sehingga pentingnya interaksi sosial dengan membatasi dan mengatur pola yang baik dan menjadikan game online sebagai permainan yang mengisi waktu luang sehingga mahasiswa terhindar dari kecanduan game online.
\end{abstract}

Kata Kunci : Pendidikan Bahasa Indonesia, Game, Dampak, Interaksi Sosial 


\section{PENDAHULUAN}

Di era ini ilmu pengetahuan dan teknologi semakin canggih, tentunya membawa pengaruh baik negatif maupun positif dikalangan mahasiswa. Manusia mampu menciptakan kreatifitas dari temuantemuan baru yang disebut game online. Game online ini bisa menjadi pengganti interaksi sosial antar mahasiswa satu dengan yang lain tanpa harus bertemu secara langsung.

Menurut penelitian Young (1996) menyatakan bahwa "game online bisa menjadi pengganti interaksi sosial melalui dunia maya dan menjadi pelarian dari realitas bagi penggunanya". Namun banyak sekali hal negatif yang didapatkan dalan permainan game online, seperti : mengakibatkan pengisolasian sosial sehingga hubungan antar teman menjadi kurang baik, kurangnya interaksi sosial secara langsung, kurang mampu mengontrol waktu dan hidupnya, bermain game secara berlebihan adalah kegiatan yang sia-sia dan tidak dapat dijadikan cara sehat dalam mengatasi stress selain itu akan membuat ketajaman mata rabun jauh berkurang. Realitanya banyak pengguna game online lupa waktu sehingga hal tersebut menjadi kebiasaannya. Berdasarkan hasil wawancara dari beberapa informan, terungkap mereka bermain Game Online selalu bergadang untuk menaikkan level game masing-masing. Informan juga mengungkapkan bahwa mereka sering terlambat datang kekampus, karena bergadang, lalai dalam mengerjakan tugas. Dalam perspektif sosiologi, orang yang sering bermain game online dan kecanduan, cenderung akan menjadi egosentris dan mengedepankan individualisme. Hal ini berbahaya bagi kehidupan sosial individu tersebut, mereka kemungkinan akan menjauh dari lingkungan sekitar dan akan bersifat tertutup, atau bahkan akan melupakan apa seharusnya kegiatan yang dia lakukan

\section{PEMBAHASAN}

Di dunia modern ini, manusia tergantung dan tidak lepas dari komunikasi. Di kehidupan saat ini alat komunikasi modern berguna untuk mempermudah berkomukasi antar individu satu dengan yang lainnya. Sebelum adanya teknologi komunikasi manusia berinteraksi secara langsung tanpa adanya alat elektronik. Teknologi sebagai membantu kehidupannya. Manusia saling membutuhkan satu sama lain dikehidupannya dan memperbaharui pergaulan atau wawasan kehidupan yang baru dan saling bekerjasama satu sama lain untuk terwujudnya suatu tujuan. Namun tetap terjadinya pertikaian, persaingan, dan sebagainya. Berikut adalah suatu proses dalam interaksi sosial

A. Interaksi Sosial

Sarwono (2009) mengatakan interaksi sosial yaitu hubungan timbal balik antara manusia satu dengan manusia lain baik itu individu maupun kelompok Koentjaraningrat (2009) mengatakan bahwa interaksi sosial terjadi jika seseorang melakukan perbuatan sedemikian rupa yang menimbulkan suatu respon atau reaksi dari individu yang lainnya. Maka akan terjadi seorang individu lainnya melakukan suatu kegiatan dan direspon oleh individu lainnya dengan cara membantu kegiatan tersebut.

B. Perilaku Sosial

Perilaku Sosial yaitu reaksi dan respon seseorang dalam stimulus dari dunia luar. Manusia dibentuk sebagaimana dari perilaku sosialnya, perilaku yang ia peroleh dari lingkungannya. Maka dalam memilah memilihi pergaulan sangatlah penting untuk menciptakan perilaku yang baik sehingga dalam kegiatan sosialnya akan membawa hal positif kepada orang banyak. Manusia mampu berfikir dan bersikap dari perilaku yang ia dapatkan dari pembelajarannya atau perilaku yang dibentuk. Maka bagaimana cara menerapkan perilaku yang diharapkan :

1. Terbiasa dengan perilaku yang diharapkan

2. Membentuk perilaku dengan pengertian didasari teori belajar kognitif yaitu belajar dengan disertai adanya pengertian.

3. Pembentukan perilaku dengan menggunakan model yang didasari 
atas teori belajar sosial (social learning theory) yang dirumuskan oleh Bandura (Bimo 2003: 16-17)

C. Game Online

Game atau permainan online sesuatu yang terdiri dari peraturan, budaya, dan play atau permaianan. Dalam sebuah permaianan, pemain terlibat dan mengikuti aturan sesuai apa yang telah ditetapkan dalam sebuah permainan atau game tersebut yang permaianan tersebut merupakan buatan atau rekayasa. Dalam sebuah permaianan terdapat aturan yang tidak boleh dilanggar dalam bermain. Dibuatnya game ini bertujuan untuk mengasah intelektual manusia atau disebut (Intelektual playability). Game adalah arena untuk membuat pemain merasa puas dalam menjalankan aksi-aksinya. Ada target-target yang dimainkan secara maksimal.

Bagaimanapun mahasiswa harus mampu menyesuaikan game online dengan kebutuhan hidupnya dan mampu membedakan sesuatu yang berdampak positif dan negatif. Berikut adalah dampak negatif dan potisif dari Game Online :

\section{A. Dampak Positif}

Pemain game atau sering disebut gamers mereka mampu melatih temannya atau pemainnya untuk memenangkan permainan dengan cara yang cepat dan mendapatkan poin atau nilai yang diinginkan. Selain itu mereka dapat :

a. Meningkatkan konsentrasi. Dengan sering bermain maka akan melatih konsentrasi pemain, konsentrasi tersebut akan meningkat karena mereka mencoba berfikir untuk menyelesaikan misi atau tugasnya.

b. Koordinasi tangan dan mata akan meningkat.

c. Meningkatnya kemampuan membaca, karena dengan bermain game online ketidak tahuan mereka dalam menjalankan permainannya akan membuat mereka cenderung membaca, sehingga minat membaca akan menambah. d. Dan yang terakhir, game online kebanyakan menggunakan bahasa inggris dalam mengoprasikannya. Dengan bermain game online akan melatih memperbanyak kosakata dalam bahasa inggris dan meningkatkan kemampuan berbahasa inggris dengan cara bermain game online.

\section{B. Dampak Negatif}

Dampak negatif game banyak sekali yang kita dapatkan jika tidak mampu menyesuaikan dan mengatur pola hidup diri masing-masing. Dengan bermain game yang berlebihan, kita akan banyak meninggalkan aktivitas yang lebih utama atau penting untuk dilakukan terlebih dahulu. Mahasiwa seharusnya mampu membedakan mana yang menjadi prioritas dalam hidupnya dan yang tidak. Dampak negatif banyak kita dapatkan pada umunya seperti : sakit mata, kurangnya sosialisasi, meninggalkan kewajiban, dan mudah emosi

C. Implemestasi Interaksi Game Online Terhadap Interaksi Sosial

Kurangnya interaksi sosial akan berdampak buruk bagi kelangsungan hidup seseorang. Kebanyakan pemain game adalah anak-anak dan remaja yang terlalu banyak menghabiskan waktunya di dunia maya. Justru itu semua akan menjauhkannya dari kehidupan duniannya. Terlalu sering bemain game online sangatlah membuat seseorang menyiayiakan waktunya dan juga dapat membuat seseorang seperti terasing dari kehidupan nyata di lingkungannya. Bermain game online, terlepas dari dampak positifnya, kita harus mengantisipasi terhadap akibat tidak baik yang dapat ditimbulkannya. Apalagi mengingat ragam pilihan game online yang variatif, dan tidak selalu edukatif. Mengingat juga bahwa permainan online ini ibarat candu yang membuat ketagihan untuk terus dan selalu bermain di semua level atau tingkatannya. Tidak hanya prestasi akademik yang menurun, namun juga berakibat tidak baik terhadap kualitas dan kuantitas interaksinya dengan masyarakat di lingkungannya. Sehingga dampak negatif dan positif game 
online sangat berhubungan dan berdampak dalam interkasi sosial dalam kehidupannya.

\section{Hasil Penelitian yang Relavan}

1. Penelitian ini dilakukan oleh Ono Shoky Eandra, dengan judul : Interaksi Sosial Pecandu Game Online Mahasiswa UNRI Kelurahan Tuah Karya Kecamatan Tampan Kota Pekanbaru. Menyimpukan bahwa, Kecanduan game online adalah ketidak mampuan seseorang untuk mengontrol tindakannya dalam memainkan game online yang mempengaruhi interaksi sosial mereka.

2.Penelitian ini dilakukan oleh Syahrul Perdana Kusumawardani, dengan judul : "Game Online Sebagai Pola Perilaku (Studi Deskriptif Tentang Interaksi Sosial Gamers Clash Of Clans Pada Clan Indo Spirit)". Menyimpulkan bahwa, jika kita menghabisakan waktu kita untuk bermain game online secara berlebihan maka menyebabkan hal tersebut menjadi suatu kebiasaan dalam hidupnya.

3. Penelitian ini dilakakukan oleh MimiUlfa yang berjudul : "Pengaruh kecanduan game online terhadap perilaku remaja di Mabes game center jalan HR. Subrantas kec. Tampan pekanbaru". Menyimpukan bahwa, sarana dalam hiburan yaitu dapat dengan bermain game online dengan berlebihan yang akan membawa dampak negatif bagi diri sendiri. Hal ini dapat berpengaruh pada penyimpangan sosial yang akan berdampak negatif pada perilaku remaja.

4. Penelitian ini dilakukan oleh Drajat Edy Kurniawan, dengan judul : "Pengaruh Bermain Game Online Terhadap Perilaku Prokrastinasi Akademik Pada Mahasiswa Bimbingan Dan Konseling Universitas PGRI Yogyakarta". Menyimpulkan bahwa semakin banyaknya mahasiswa yang bermain game online, semakin tinggi mahasiwa untuk berperilaku prokrastinasi atau tugas-tugas akademik

5.Penelitian ini dilakukan oleh Yohanes R.D.S dan Jusuf T.P. Dengan judul :

"Hubungan kecanduan game online terhadap penyesuaian sosial pada remaja".
Menyimpulkan, game online menyebabkan sosialisasi yang buruk selain itu penyesuaian sosial yang buruk akan mempengaruhi psikologis dan terganggunya hubungan dengan dunia sekitar atau dengan lingkungannya

6. Penelitian ini dilakukan oleh Eka Rusnani Fauziah. Dengan judul : "Pengaruh Game Online Terhadap Perubahan Perilaku Anak Smp Negeri 1 Samboja". Menyimpulkan bahwa, kita harus mampu mengontrol diri dari hal hal negatif menjadi suatu hal yang positif agar perkembangan Game Online tidak merajalela.

7.Penelitian ini dilakukan oleh Krista Subakti. Dengan judul : "Pengaruh Game Online Terhadap Remaja". Menyimpulkan bahwa, bermain game dapat membuat seseorang menjadi kecanduan jika dilakukan secara terus menerus. Jika pelajar yang bermain game secara terus menerut tanpa henti dan sangat aktif pada aktivitas game, dan mengurangi waktu belajar. Hanya saja para pelajar sudah terbiasa dengan Game Online yang di mainkannya, dan memiliki ketagihan tersendiri membuatnya melupakan tugas pokok yang harus mereka kerjakan.

8. Penelitian ini dilakukan oleh Ach Fauzi. Dengan judul : Pengaruh Game Online PUBG (Player Unknow's Battle Ground) Terhadap Prestasi Pesarta didik. Menyimpulkan bahwa, Semakin populernya game online mengakibatkan gamers (pemain game) menjadi ketagihan akan game tersebut. Fase ketagihan dalam memainkan games ialah situasi dimana seseorang gamers sangat susah dalam melepaskan dirinya dari gamenya tersebut.

9.Penelitian ini dilakukan oleh Dona Febriandari, Fathra Annis Nauli, dan Siti Rahmalia HD. Dengan judul : "Hubungan Kecanduan Game Online Terhadap Identitas Diri Remaja". Menyimpulkan bahwa, game online membawa hiburan, tidak hanya itu game online juga memberika tantangan misi yang menarik untuk dimainkan oleh pemainnya dengan menyelesaikan secara cepat. 
10. Penelitian ini dilakukan oleh Satria Sagara dan Achmad Mujib Mansyur. Dengan judul : "Gambaran Online Gamer dan Peserta Didik". Menyimpulkan bahwa, gambaran online gamer dapat diindikasikan kecenderungan subjek bermain online game dengan durasi waktu yang berlebihan sehingga mengganggu aktivitas pendidikan, kesehatan, dan sosial dalam lingkungan.

11.Penelitian ini dilakukan oleh Rahmad Nico Suryanto. Dengan judul : "Dampak Positif dan Negatif Permainan Game Online Dikalangan Pelajar". Menyimpulkan bahwa, dalam bermain game pelajar harus mampu mengontrol dirinya sendiri agar tidak berlebihan dalam menggunakan game online, bermain game online dengan sesuai kebutuhan dan tidak mengganggu aktivitas yang utama.

12. Penelitian ini dilakukan oleh Teuku R.S. Dengan judul : "Pengaruh bermain game online terhadap perilaku komunikasi remaja". Menyimpulkan bahwa, dengan permaina game online adalah sesuatu yang dapat mengilangkan kebosenan hingga menghabiskan waktu yang berjam jam. Fitur yang terdapat pada game online menjadi sebab salah satunya. Selain itu, tim dan taktik yang membuat pemain betah dalam memainkannya.

13.Penelitian ini dilakukan oleh Aditia Christianti. Dengan judul : "Studi Deskriptif: Psychological Well Being pada Remaja yang Kecanduan Bermain Game Online di Surabaya". Menyimpulkan bahwa, sebagian besar subjek berlebihan dalam menggunakan game, tergolong sebagai kategori sedang dan tinggi. frekuensi dan durasi bermain game online juga rata-rata mendukung subjek untuk menjadi kecanduan.

14.Penelitian ini dilakukan oleh Pratiwi Indah Palupi, Nanang Wiyono, dan Ari Probandari. dengan judul : "Intensitas bermain video game online berhubungan dengan kapasitas memori kerja" : Studi Cross-Sectional pada mahasiwa fakultas kedokteran UNS. Menyimpulkan bahwa, dalam bermain game online dengan intens dapat menjadi hal yang positif dalam memori kerja otak menurut Mahasiswa Program Studi Jurusan Kedokteran di UNS.

15. Penelitian ini dilakukan oleh Eka Ayu Purnama Lestari. Dengan judul : "Pengaruh Language Games Terhadap Kemampuan Berbahasa Inggris". Menyimpulkan bahwa, Penelitian ini memaparkan pengaruh language games terhadap kemampuan berbicara mahasiswa yang mencakup kelancaran, pelafalan, dan ketepatan kalimat.

16.Penelitian ini dilakukan oleh Dahlia. Dengan judul : "Game Online dan Interaksi Sosial dan Kualitas Interaksi Sosial Gamer". Menyimpulkan bahwa, bermain game yang berlebihan akan menurunkan interaksi sosialnya dengan masyarakat dan kehidupannya. Hal tersebut harus mendapat penanganan serius dengan melibatkan keluarga, guru, dan orangtua.

17. Penelitian ini dilakukan oleh Nurlaela. Dengan judul : "Dampak Game Online Terhadap Moral Anak Di Desa Malili Kecamatan Malili Kabupaten Luwu Timur". Menyimpulkan bahwa, Pengawasan kepada anak tentang bahaya game online haruslah dilakukan dengan memberi pengertian dan masukan langsung kepada anak. Pengertian yang diberikan kepada anak pengertian yang positif tentang manfaat (game online), dan bahaya yang ditimbulkan dari seringnya memainkan game online.

18.Penelitian ini dilakukan oleh Linda Setiawati, Elni Yakub, dan Tri Umari. Dengan judul : "Student Of The Online Game Addiction And Conditions Of Psychological In SMA TRI BHAKTI Pekanbaru". Menyimpulkan bahwa, kondisi psikologis siswa yang kecanduan game online berada pada kondisi emosi marah yaitu kesal jika diatur dalam belajar, kondisi psikologis emosi senang yaitu gembira jika pulang sekolah lebih awal untuk bermain game online.

19. Penelitian ini dilakukan oleh Siti Kolipah dan Shrimarti Roekmini Devy. Dengan judul : "Pengaruh Ketahanan Keluarga Terhadap Kegemaran Bermain Game Online Pada Siswa SD Di Kelurahan Mulyorejo". 
Menyimpulkan bahwa, berharap orangtua mampu berkomunikasi dengan baik dengan anak-anak mereka dalam penanganan dampak buruknya game online. Selain itu mereka dapat terbuka dalam aspirasinya dan anak tidak akan merasa kurang perhatian dari orangtua.

20. Penelitian ini dilakukan oleh Tri Rizqi Ariantoro. Dengan judul ; "Dampak Game Online Terhadap Prestasi Belajar Pelajar". Menyimpulkan bahwa, Gunakanlah internet sesuai kebutuhan jangan untuk merugikan oranglain dan hal yang dapat menyebabkan suatu masalah. Gunakanlah internet untuk bahan atau media pembelajaran untuk menata masadepan yang diinginkan diikuti dengan intelektual yang kritis dan luas.

\section{METODE PENELITIAN}

Dalam penelitian ini menggunakan metode kualitatif. Penelitian kualitatif merupakan penelitian yang mempelajari tentang fenomena yang terjadi atau yang dialami. Dengan cara mendeskripsikan dalam suatu kat-kata maupun bahasa, dengan menggunakan metode alamiah. Dalam menyelidiki, menggambarkan, menemukan, dan menjelaskan dari pengaruh sosial yang tidak dapat diperjelaskan. Sehingga dapat diukur dengan pendekatan kuantitatif.

Metode ini diambil karena, penelitian ini tidak menggunakan penelitian yang baku, tujuan penelitian ini mencari dan memahami yang terdapat dalam data, mengumpulkan data dengan prinsip fenomenologis dan penelitian tersebut disebut penelitian inquiri naturalistik mendalami penelitian yang sifatnya alamiah.

Tujuan akhir dari penelitian ini untuk mendapat interpretasi pemahaman individu terhadap fenomologi yang terjadi terhadap individu berdasarkan makna dibalik situasi yang sedang dialami. "Fenomologi dilakukan dalam situasi yang dialami atau murni sehingga tidak ada batasan dalam memaknai atau memahami suatu fenomena yang dibahas". (Cresswell, 2012).
HASIL DAN PEMBAHASAN

A. Memahami bagaimana interaksi sosial mahasiswa pecandu game online dengan lingkungan sosial hubungannya akan menjadi kurang baik dan komunikasi secara langsung akan terganggu.

Di Era kemajuan teknologi dan komunikasi sekarang ini, puluhan orang sudah mampu menggunakan permainan online dari gatget atau elektorik yang mereka miliki. Berbagai macam permainan sudah terpenuhi dalam dunia maya saat ini selain itu permainan ini juga menambah daya tarik penggunanya. Ada persaingan dan kompetisi sehingga membuat para pemain untuk tampil atau melakukannya dengan maksimal dan pantang menyerah. Permainan game online juga sangat menarik untuk digunakan atau dimainkan oleh para gamers (pemain game) karena selain audio visualnya yang menarik, karakter yang ditampilkan membuat pemain betah dalam bermain game. Banyak pecandu game online kehilangan konsentrasi di dunia nyata. Karena kurangnya aktivitas di dunia nyata. Yang lebih berbahaya dari kecanduan game online adalah timbulnya perilaku agresif sebagai luapan emosi dalam kegagalan dalam melawan lawan atau musuh di game online tersebut. Misalnya meluapkan dengan cara merusak benda dan mudah marah terhadap orang sekitar. Maka dari itu, banyak sekali yang kita dapatkan dari bahayanya kecanduan dalam bermain game online. Secara kesehatan kecanduan ini menyebabkan mood kurang bagus, menurunnya kestabilan mental, public speaking yang buruk, berperilaku buruk, kelainan neurotransmitter dopamine, memicu halusinasi, gangguan sirkulasi seperti pusing kepala, migrain atau vertigo, penyusutan otak, mengganggu fungsi daya ingat, dan kelainan respon otak. Dampak tersebut bisa terjadi jika tidak dapat mengendalikan diri dengan kecanduannya game online, mengurangi dalam bermain game menjadi solusi yang tepat dalam pengurangannya dampak tersebut.

Dampak negatif yang tanpa kita sadari menunda aktivitas lainnya. Dengan bermain game online secara berlebihan akan 
terjadinya seperti malas mandi, kurang tidur, depresi, stres, kehilangan napsu makan, agresif, sakit mata, mudah lelah, dan yang terakhir mengasingkan diri terhadap lingkungan terdekatnya. Tujuan dari pembahasan ini yaitu pengaruh game online terhadap interaksi sosial dalam sisi negatif, biasanya pemain game atau sering disebut istilah "gamers" sering berkomunikasi satu sama lain di dunia maya, tetapi mereka malas bersosialisasi dengan teman-temannya didunia nyata, game online juga memiliki tingkat kecanduan yang tergolong tinggi karena gamer akan mengalami kepuasan sehingga mereka akan mengulangi kegiatannya sehingga mempengaruhi kehidupan sosial mereka. Mereka cenderung akan menarik diri dari kehidupan sosialnya dan kerap menyendiri. Tidak hanya orang yang kecanduan game online tetapi orang yang dulu suka bersosialisasi akan merasa ketagihan bermain game online dengan mengasingkan diri dan menarik diri dari keramaian dan fokus terhadap permainnya tersebut.

Mahasiswa seharusnya sudah mampu membedakan mana hal yang produktif atau bermanfaat dan yang tidak, sebaiknya mereka lebih fokus terhadap masa depannya dibandingan dengan membuang-buang waktu dengan bermain game online seharian. Lebih parahnya lagi jika terjadinya bolos kuliah hanya karna lebih memprioritaskan bermain game online dari pada kuliah. Kecanduan game online merupakan sebagai salah satu gangguan mental karena dengan perilaku gigih dan mengulang kegiatan tersebut sehingga menyampingkan kepentingan hidup lainnya. Seharusnya mahasiswa sudah mampu membagi waktu antara bermain game online di waktu luangnya dengan memikirkan dampak yang terjadi jika sudah kecanduan game online. Game sebenarnya bertujuan untuk menghibur dari kalangan anak kecil hingga dewasa, games juga penting dalam perkembangan otak manusia untuk meningkatkan konsentrasi dan melatih untuk memecahkan masalah dengan waktu yang singkat. Tetapi kebanyakan dari pengguna game sudah kecanduan dalam penggunaannya.
Pentingnya bersosialisasi dari pada mengabiskan banyak waktu dalam bermain game karena manusia tidak bisa memenuhi kehidupannya sendiri, mereka membutuhkan orang lain untuk membantu dan memenuhi kebutuhannya, adanya keinginan untuk berkomunikasi, setiap individu membutuhkan interaksi antar sesama secara langsung untuk memenuhi kebutuhannya, sosialisasi dalam mengembangkan potensi demi menjadi pribadi yang baik dalam masyarakat, dan memberikan dampak positif pada fungsi otak karena dengan berinteraksi sosial manusia mampu meningkatkan memori otak. Bermain game online mampu merusak sistem saraf otak manusia, dengan begitu, pentingnya bersosialisasi dengan berinteraksi dengan sesame akan melatih daya ingat dan pemikiran mahasiswa dan mencegah terjadinya demensia. Demen sia adalah gejala pemikiran yang menyebabkan gangguan aktivitas sehari-hari, gejala ini seperti mudah lupa dan kurangnya interaksi sosial yang menghambat aktivitas sehari-hari. Karena, lebih baik mencegah dari pada mengobati.

Berikut adalah pengambilan data dari beberapa informan melalui pertanyaanpertanyaan yang diberikan peneliti :

1. Dampak negatif game pada diri sendiri (RI/19/4/2020). Lupa tidur, lupa berolahraga, lupa makan dan lupa aktivitas lainnya (Rizki Inferno, 19 April 2020)

Dampak negatif game dalam bersosialisasi (RI/19/4/2020)

Membuat malas keluar rumah untuk bersosialisasi lebih mementingkan game, menjadi tertutup terhadap siapapun karena game (Rizki Inferno, 19, April, 2020)

2. Dampak negatif game pada diri sendiri (ARA/19/4/2020).

Menjadikan diri menjadi malas dan sering menghabiskan waktu menutup diri, kurangnya berinteraksi dengan dunia maya maupun dunia luar, dan sering melupakan semua kewajiban sebagai remaja contohnya sholat, membantu orangtua, dan belajar. Selain itu merusak fungsi otak itu 
sendiri (Alvian Ricky Afandi, 19, April, 2020)

Dampak negatif game dalam bersosialisasi (AR/19/4/2020).

Menjadi seorang yang penuh keraguan dan malu-malu dengan lingkungan sekitar. Selalu bertindak atau berlaku tidak seperti kebanyakan orang dan kurang pergaulan dengan lingkungan masyarakat (Arvian Ricky Avandi, 19, April, 2020).

3. Dampak negatif game pada diri sendiri (RAW/19/4/2020).

Mata menjadi sakit dan jika kalah menjadi emosi (Reksya Asmara Wiyanandatama)

Dampak negatif game dalam bersosialisasi (RAW/19/4/2020).

menjadi bahan omongan teman jika berkumpul sambil bermain game online (Reksya Asmara Wiyanandatama)

Yang diperoleh dari pengumpulan data melalu wawancara dengan informan tersebut bahwa mereka lebih mementingkan kehidupan nyatanya dalam bergaul dengan teman-temannya dan juga lebih mementingkan kewajibannya dari pada bermain game online, selain itu saat mereka terlalu asik bermain game mereka merasakan banyak hal negatif yang mereka dapatkan karena keseringan bermain game, game online juga memperlambat dan menunda aktivitas yang seharusnya mereka kerjakan. Dari pertanyaan yang dilontarkan akan membuka pemikiran mereka dengan menyadari dampak buruknya game online bagi dirinya. Mereka akan menyadari pentingnya bersosialisasi dan memprioritaskan hal-hal penting dikehidupan nyatanya untuk kegiatan yang bermanfaat. Sehingga mereka mampu membedakan mana yang harus didahulukan dan yang tidak.

Selain itu hal tersebut yang sudah mampu mengontrol membagi waktu dalam bermain game online. Hanya diri sendiri dan teman sekitarnyalah yang mampu mengurangi kecanduan dalam bermain game online. Kewajiban orangtua seharusnya sudah tidak lagi mengingatkan karena sebagai mahasiswa harus mampu mengelola waktunya dengan sebaik dan seefisien mungkin. Walaupun di era modern ini teknologi semakin canggih kita seharusnya tidak lupa berinteraksi terhadap sesama karena pentingnya berinteraksi antar sesama dibandingkan membuang-buang waktu dengan bermain game secara berlebihan. Hal yang baik harus dipertahankan. Karena dengan cara bersosialisasi kita dapat menambah pengetahuan kita. Berinteraksi dengan sesame sangatlah penting, cobalah perbanyak berinteraksi dengan sesama mahasiswa satu dengan mahasiswa lainnya, dengan keluarga, dengan tetangga, dan dengan lainnya maka akan merasakan pentingnya berinteraksi satu sama lain dibandingkan sibuk bermain game online.

\section{B. Memahami bahwa tidak selalu game online mempunyai dampak negatif karena manusia mampu menciptakan kreatifitas dari temuan-temuan baru seperti permainan game online}

Di era globalisasi ini teknologi dan informasi (TIK) menjadi hal umum yang penting bagi kehidupan manusia saat ini. Manusia tidak bisa lepas dari yang namanya teknologi karena dalam melakukan dan mencari solusi apapun manusia menggunakan teknologi. Teknologi mempermudah manusia dalam melakukan aktivitasnya. Teknologi juga sulit untuk dikontrol karena teknologilah yang menyatukan dunia.

Di Indonesia abad ke-21 perkembangan teknologi kian hari kian pesat dari zaman ke zaman. Hal ini dapat kita lihat dari banyaknya penggemar game online dari anak-anak hingga orang dewasa. Selain sebagai hobi atau hanya sebagai penghilang rasa bosan game juga bisa di gunakan untuk melatih kreativitas dan strategi yang mengasa pikiran. Teknologi game awal mulanya diciptakan oleh A.S Douglas pada tahun 1950 di university of cambrigade melalui tesis dalam rangka "interaksi antara computer dan manusia". Seiring berkembangnya teknologi permasalahan game adalah apakah hobi atau bakat tersebut bisa kita jadikan sebagai cita-cita atau bahkan menjadi penghasilan untuk diri kita?. 
Sebagian orang beranggapan bahwa hobi bermain game online hanya akan memberikan dampak buruk atau dampak negatif bagi penggunannya, padahal di luar negeri pekerjaan sebagai game desain adalah suatu hal yang menjanjikan. Untuk menunjang kemajuan teknologi game di Indonesia, pemerintahan berupaya untuk mengembangkan hobi mereka salah satunya dalah dengan membuka jurusan teknologi game di beberapa Univeristas di Indonesia seperti Institut Teknologi Sepuluh November, Politehnik Elektro Negeri Surabaya dan ITB (Institut Teknologi Bandung). Bukan hanya itu pemerintahan juga memberikan beasiswa kepada mahasiswa berprestasi yang

Menyalurkan bakatnya ke dalam bidang akademi tersebut sehingga hal ini bisa memicu semangat belajar bagi mahasiswa. Dalam bermain game online mahasiwa mampu menyalurkan kreatifitasnya seperti :

1. Sebagai penulis di media gaming Situs berita yang menjelaskan dan cara menggunakan game online dengan baik.

2. Menjadi caster atau komentator dalam turnamen game

Mahasiswa yang ahli dibidang game dan mampu berbicara dengan lancar, bakat kamu dapat dikembangkan dengan mengikuti atau mencalonkan diri dengan menjadi komentator game online sebagai waktu luang.

3. Streamer gamer

Kreatifitas inilah yang biasanya menghasilkan banyak pendapatan atau pemasukan, karena banyak platform livestream yang marak di pertontonkan. Semakin banyak subscribe dan viewer yang kamu dapatkan akan semakin banyak loyaliti yang kamu peroleh.

4. Menyalurkan bakat menjadi influencer, endorser, dan brand ambassador

Banyak mahasiswa sekarang memanfaatkan digital untuk memperoleh pendapatan dari sini. Dengan modal kreativitas yang tinggi serta niat mahasiswa mampu menyalurkan kreatifitasnya dalam bermain game dengan menjadi influencer, endorser, dan brand ambassador.

Tidak semua game online berdampak negatif, itu semua tergantung individu masing-masing. Namun banyak dampak positif yang kita dapatkan game online secara langsung yang meliputi :

a) Game dapat online dapat dimainkan secara langsung dengan pemain game lainnya dengan berkomunikasi satu sama lain. Contoh game yakni : Mobile Legend, Free Fire, PUBG dan masih banyak game lainnya.

b) Dalam terjadinya wabah Covid-19 Game online penetral manusia agar tidak stress karena tidak bisa berinteraksi sesama temannya secara langsung, sehingga mereka dapat bermain bersama dan berinteraksi atau berkomunikasi secara langsung melalui game online tersebut.

c) Manusia satu dengan manusia lainnya yang tidak kenal satu sama lain dapat berinterkasi dan berkomunisi sehingga menambah ruang lingkup pertemanan.

d) Bagi mahasiswa introvert yang tidak suka melakukan aktivitas di luar, mereka lebih tertutup. Sehingga game online menjadi solusi ketika dia malu berinterkasi secara langsung kepada orang lain dengan cara bermain bersama.

e) Game online cenderung bertempur atau berkelompok sehingga menyatukan individu satu dengan individu lainnya untuk berinteraksi dengan berkerja sama dalam memecahkan masalah atau memenangkan pertandingan secara bersama-sama.

f) Bermain game mampu menjalin silahturahmi dan menambah pertemanan dalam media sosial. Mereka dapat bertukar sosial media seperti instagram, twitter dan yang lainnya yang akan menjadi baik itu kawan didunia maya maupun kawan didunia nyata.

g) Banyak game online membutuhkan kerjasama tim untuk memenangkan misi. Karena itu, mahasiswa harus 
dapat mengenal satu dengan yang lainnya agar mampu memenuhi strategi agar tujuan dapat tercapai. Mahasiswa dapat belajar bekerjasama dalam sebuah kelompok. Dan nantinya bisa diaplikasikan dikehidupan sehari-hari.

h) Jika mampu bermain game online dengan baik, kamu dapat mencoba membuat game online seperti cabang olahraga yang disebut ESport (Electronic Sports). Mahasiswa dapat mengikuti turnamen kelas internasional. Selain menambah penghasilan mahasiswa akan menambah ruang lingkup pertemanan.

i) Tuna Wicara, mereka dapat mencoba bermain game online. Dan mereka dapat berinterksi dengan banyak orang.

j) Game online menjadi solusi kedua jika interaksi sosial secara langsung tidak dapat berjalan dengan baik dan memiliki kendala, dengan bermain game online menjadi solusi yang tepat, selain berkomunikasi berinteraksi satu dengan yang lainnya mereka dapat bermain secara bersama. Pilihlah game online yang dapat berinteraksi secara langsung jika mengalami kesulitan dalam berinteraksi.

Berikut adalah pengambilan data dari beberapa informan melalui pertanyaanpertanyaan yang diberikan peneliti :

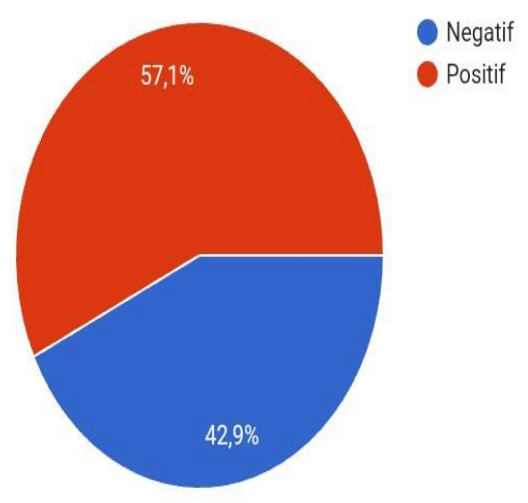

Dari hasil penelitian terealisasikan bahwa apakah game online lebih banyak berdampak negatif atau positif dalam interaksi sosial mereka. kesimpulan diagram yang ditampilkan google form menunjukan bahwa, Mahasiswa cenderung positif game online menjadi salah satu cara mereka dalam mengurangi kebosenan diwaktu luang dengan berinterkasi dengan bermain jarak jauh yang menyenangkan. Contoh salah satunya yakni :

1. (WK/26/04/2020)

Membuat lebih senang mengenal orang-orang baru yang intinya saling memahami suatu yang kita lakukan saat didalam game maupun diluar game. Saat berinteraksi dengan sesama kita tidak canggung, sebab sudah terbiasa saat digame maupun diluar game (Widagdo Kuswantoro, 26, April, 2020).

2. (RF/26/04/2020)

Dalam berinteraksi dapat menambah teman, menambah keakraban teman, dan dapat mengutarakan sesuatu dengan lisan kita apabila emosi, melatih koordinasi. Jika bermain game bersama teman kita saling membantu apabila hero atau player kita diserang musuh saat bermain game bersama teman (Rizqi Fadli, 26, April, 2020)

3. (K/26/04/2020)

Dapat menambah teman (Krisna, 26, April, 2020).

4. (B/26/04/2020)

Menambah keakraban pertemanan, menambah teman dalam game, dan memperluas bahasa yang dipahami (Bubby, 26, April, 2020).

Mahasiswa merasa mereka sudah mampu mengendalikan hal apa yang harus diprioritaskan dan yang tidak. Sebagian mereka mengatakan game online menjadi penghambat dalam berinteraksi sosial karena sibuk dengan bermain game masing-masing. Namun, sebagian dari mereka mampu menempatkan dimana dan kapan mereka harus bermain sehingga tidak menghambat mereka dalam berinteraksi secara langsung. Mereka berfikir bahwa seharusnya mahasiswa sudah mampu mengendalikan hawa nafsu dalam bermain game secara berlebihan. Mereka harus bisa membagi waktu dengan dunianya sehingga game online akan berdampak positif bagi dirinya. 
Prespektif dahulu yaitu game online menjadi suatu hal negatif yang umum diperbincangkan dengan kecanduannya bermain gadget. Tetapi, manusia atau mahasiswa sekarang tidak hanya bermain game, mereka mampu menghabiskan waktu berjam-jam tanpa berinterkasi secara langsung dengan keluarga, teman dan lainnya dengan melakukan aktivitas seperti bermain instagram, twitter, streaming film dan sebagainya. Sehingga berinteraksi dengan bermain game online bukan selalu menjadi hal yang buruk. Sebagian game menerapkan batasan dalam bermain seperti 6jam atau 7jam perhari, jika lebih dari itu mereka tidak dapat memainkannya dan menggunakannya esok hari.

\section{SIMPULAN}

Berdasarkan hasil analisis yang telah dipaparkan diatas mengenai game online dan pengaruh interaksi sosial di kalangan mahasiswa Universitas Muhammadiyah Surakarta, maka penulis menyampaikan beberapa hal sebagai berikut:

1. Memahami bagaimana interaksi sosial mahasiswa pecandu game online dengan lingkungan sosial hubungannya akan menjadi kurang baik dan komunikasi secara langsung akan terganggu. Seseorang yang banyak menghabiskan waktunya dalam bermain game online akan menjauhkan mereka dengan kehidupan dunianya. Interaksi sosial adalah suatu kebutuhan dalam diri manusia, karena manusia tidak bisa mampu hidup sendiri, mereka saling membutuhkan satu sama lain. Banyak kegiatan yang akan mereka tinggalkan seperti, mahasiwa cenderung malas mengerjakan tugas kuliahnya dan lebih mementingkan bermain game online. Maka sangat penting mahasiswa mampu membagi waktu mereka bermain game online dengan berinteraksi dengan dunia luar. Banyak manfaat interaksi sosial bagi diri sendiri yaitu : manusia dapat mengenal lingkungan barunya, saling mempererat tali silahturahmi, dan mampu menghindari konflik antar sesama. Mahasiswa yang kecanduan game online cenderung malas dan tidak mau berinteraksi terhadap sesama karena sibuk dengan dunia game onlinenya masing-masing, mereka cenderung acuh tak acuh dalam dunia luar yang mereka fokuskan hanya bermain game online dengan menyendiri tanpa beradaptasi dengan orang sekitar. Banyak hal negatif yang akan didapatkan jika mahasiswa cenderung kecanduang game online, banyak kegiatan yang bermanfaat yang akan mereka tinggalkan demi mengedepankan game onlinenya tersebut. Maka sebaiknya mahasiswa meminimalisir dan seharusnya mampu beradaptasi mana yang menjadi prioritas dalam hidup dan yang tidak serta sebaikanya mahasiwa bermain game diwaktu luang mereka.

2. Memahami bahwa tidak selalu game online mempunyai dampak negatif karena manusia mampu menciptakan kreatifitas dari temuan-temuan baru seperti permainan online atau bisa disebut game online. Game online tidak selalu buruk jika mahasiswa mampu memanfaatkannya dengan baik. Beberapa hal positif yang didapatkan dalam bermain game yaitu : menambah teman baru dalam dunia maya, memperluas bahasa yang mereka pahami, mampu berinteraksi dengan cara berkomunikasi dalam game online karena adanya keterjangkauan jarak untuk bertemu, dan menambah keakraban dalam pertemanan. Mahasiwa juga mampu meningkatkan kreativitas mereka dibidang Teknologi Informasi dan Komunikasi dengan mendalami pemahaman mereka dalam bidang gaming seperti : penulis dibidang gaming, menjadi caster atau komentator dakam ternamen game, streamer gamer, dan menyalurkan bakat menjadi influencer. Dengan begitu tidak selalu game online menjadi suatu hal yang buruk jika kita sebagai mahasiswa mampu menggunakannya dengan waktu dan cara yang tepat.

\section{DAFTAR PUSTAKA}


Ariantoro, T. R. 2016. “Dampak Game Online terhadap Prestasi Belajar Siswa". JUTIM (Jurnal Teknik Informatika Musirawas)", 1(1): 45-49. DOI: https:// doi.org/10.32767/jutim.v1i1. $\underline{22}$

Christianti, Aditia; Nanik Nanik, \& Vivi Setiono. 2016. "Studi Deskriptif: Psychological Well Being pada Remaja yang Kecanduan Bermain Game Online di Surabaya". Calyptra, 5(1): 1-2. DOI: http://www.journal.ubaya.ac.id/ind ex.php/jimus/article/view/

Dahliah. 2015. “Game Online dan Interaksi Sosial Menyorot Intensitas dan Kualitas Interaksi Sosial Gamer". Paradiguna Madani, 2(1): 51-72. DOI: http:// ejurnal.uij.ac.id/index.php/P AR/article/download/41/38

Eandra, Ono Shoky. 2019. "Interaksi Sosial Pecandu Game Online Mahasiswi UNRI Kelurahan Tuah Karya Kecamatan Tampan Kota Pekan Baru". Jom Fisip, 6(2): 1-13. DOI: https://jom.unri.ac.id/index.php/JO MFSIP/article/download/25227/244 $\underline{41}$

Fauzi, Ach. 2019. "Pengaruh Game Online PUBG (Player Unknown's Battle Ground) terhadap Peserta Didik". ScienceEdu, 2(1): 61-66. DOI: https:// doi.org/10.19184/se.v2i1.117 $\underline{93}$

Fauziah, Eka Rusnani. 2013. “Pengaruh Game Online terhadap Perubahan Perilaku Anak SMP Negeri 1 Samboja". Ejournal Ilmu Komunikasi, 1(3): $1-16 . \quad$ DOI: https:/ / www.ejournal.ilkom.fisipunmul.ac.id/site/wpcontent/uploads/2013/07/ejournal $\%$ 20eka\%20RF\%20(07-01-13-03-4559).pdf

Febriandari, Dona, \& Fathra Annis Nauli. 2016. "Hubungan Kecanduan Bermain Game Online terhadap Identitas Diri Remaja". Jurnal Keperawatan Jiwa, 4(1): 50-56. DOI: http://103.97.100.145/index.php/JKI $\angle$ article/view/3904

Ibsik, Sangkala. 2017. "Dampak Game Online terhadap Moral Anak di Desa Malili
Kecamatan Malili Kabupaten Luwu Timur". Jurnal Tomalebbi, (1): 93-104. DOI:

https:/ / ojs.unm.ac.id/tomalebbi/arti cle/view/3669/2084

Kadarisman, Yoskar, \& Rahmad Nico Suryanto. 2015. “Dampak Positif dan Negatif Permainan Game Online di Kalangan Pelajar". Doctoral Dissertation, 2(2): 1-15. DOI: https://www.neliti.com/publications /32394/dampak-positif-dan-negatifpermainan-game-online-dikalanganpelajar

Kolipah, Siti, \& Shrimarti Roekmini Devy. 2017. "Pengaruh Ketahanan Keluarga terhadap Kegemaran Bermain Game Online pada Siswa SD di Kelurahan Mulyorejo". Jurnal Promkes: The Indonesian Journal of Health Promotion and Health Education, 4(1): $\quad$ 104-115. $\quad$ DOI: http://dx.doi.org/10.20473/jpk.V4.I1 $.2016 .104-115$

Kurniawan, Drajat Edy. 2017. "Pengaruh Intensitas Bermain Game Online terhadap Perilaku Prokrastinasi Akademik pada Mahasiswa Bimbingan dan Konseling Universitas PGRI Yogyakarta". Jurnal Konseling Gusjigang, 3(1): 97-103. DOI: https:// doi.org/10.24176/ikg.v3i1.11 $\underline{20}$

Kusumawardani, Syahrul Perdana. 2015. "Game Online Sebagai Pola Perilaku Studi Deskriptif Tentang Interaksi Sosial Gamer Clash of Clash pada Clan Indo Spirit". Jurnal Antropologi Fisip Universitas Airlangga, 4(2): 154163.

DOI:

http://journal.unair.ac.id/downloadfullpapers-aun83bacf15affull.pdf

Palupi, Pratiwi Indah, Nanang Wiyono, \& Ari Probandari. 2017. “The Intensity of Playing Video Games Relates Positively to Working Memory Capacity: Cross-Sectional Study in Students of Faculty of Medicine at Sebelas Maret University Surakarta". Nexus Kedokteran Komuntas, 6(2): 18-32.

DOI:

http://jurnal.fk.uns.ac.id/index.php/ 
Nexus-Kedokteran-

Komunitas/article/view/1135

Sagara, Satria, \& Achmad Mujab Masykur. 2018. "Gambaran Online Gamer". Doctoral Dissertation, 7(2): 1-11. DOI: http:/ / eprints.undip.ac.id/61533/

Santoso, Yohanes Rikky Dwi, \& Jusuf Tjahjo Purnomo. 2017. "Hubungan Kecanduan Game Online Dota 2 terhadap Penyesuaian Sosial pada Remaja". Pax Humana, 4(1): 27-44. DOI: $\quad$ http://www.jurnalilmiahpaxhumana.org/index.php/PH/artic le/view/99

Setiawat, Linda. 2018. "Student of The Online Game Addiction and Conditions of Psychological in SMA Bhakti Peanbaru". Jom Fkip, 5(1): 1-15. DOI: https://jom.unri.ac.id/index.php/JO MFKIP/article/download/20017/193 $\underline{56}$

Surbakti, Krista. 2017. "Pengaruh Game Online terhadap Remaja". Jurnal Curere, 1(1): 28-38. DOI: http://dx.doi.org/10.36764/jc.v1i1.20

Syahputra, Teuku Romy. 2018. “Pengaruh Bermain Game Online terhadap Perilaku Komunikasi Remaja (Studi pada Mahasiswa Pemain Game Online di Fakultas MIPA Jurusan Informatika Universitas Syiah Kuala Banda Aceh)". Jurnal Ilmiah Mahasiswa Fakultas Ilmu Sosial, 3(1): 1-12.

DOI:

http://jim.unsyiah.ac.id/FISIP/articl e/view/6022

Trisnadewi, Komang, \& Eka Ayu Purnama Lestari. 2018. "Pengaruh Language Games terhadap Kemampuan Berbicara Bahasa Inggris Kulturistik". Jurnal Bahasa Budaya, 2(1): 66-78. DOI:

https:// doi.org/10.22225/kulturistik. $\underline{2.1 .674}$

Ulfa, Mimi, and Risdayati Risdayati. 2017. "Pengaruh Kecanduan Game Online terhadap Perilaku Remaja di Mabes Game Center Jalan Hr. Subrantas Kecamatan Tampan Pekan Baru". Doctoral dissertation, 4(1): 1-13. DOI: https://jom.unri.ac.id/index.php/JO MFSIP/article/view/13841/13402 